\title{
BAPTISM OF FIRE
}

\author{
HOW JOURNALISM STUDENTS FROM THE \\ UNIVERSITY OF THE SOUTH PACIFIC COVERED \\ THE SPEIGHT PUTSCH AND ITS AFTERMATH
}

\author{
PHILIP CASS
}

\begin{abstract}
During the violent coup staged by businessman George Speight in Fiji in May 2000, accurate information about what was happening was often restricted to a handful of Fijian websites. On some occasions the only site still operating-and the only source of information for readers outside Fiji-was the one run by the journalism programme at the University of the South Pacific. Journalism students began to cover the unfolding events as an academic exercise but, before long, their newspaper and its associated website became vital links to the outside world. Despite attempts to suppress it, the student website was often the sole source of news for people outside Fiji as commercial websites went off line. Their work was rewarded with international acclaim, including awards for journalism education. Ten months later, the journalism students were again on assignment, reporting the complexities of the elections that followed the coup.
\end{abstract}

Key words: George Speight; University of the South Pacific; Fiji; coup; journalism; students.

\begin{abstract}
A
MUTED, RESIGNED AIR hung over Suva. It was 20 July 2001, and having survived the violence of the Speight putsch (it would be too dignified to call it a coup) the people of Fiji were waiting for the August elections.

Despite an apology for the attempted coup from President Iloilo and assurances by defence force commander Commodore Frank Bainimarama that

Philip Cass taught journalism at the University of the South Pacific from 1995 to 1997 and started the journalism students' newspaper Wansolwara. He has written widely on the Pacific in academic journals and general publications. He now teaches in the College of Communications and Media Sciences at Zayed University in Abu Dhabi in the United Arab Emirates and is researching an article on the role of Fijian members of the SAS in Oman in the early 1970s. The author would like to say thank you to David Robie, namaste to Prince Gopal Lakshman and vinaka vakelevu to USP's journalism students.
\end{abstract}

Correspondence address: Zayed University, PO Box 4783, Abu Dhabi, United Arab Emirates. E-mail: philip.cass@zu.ac.ae 
the army would respect the outcome of the election, many people were reluctant to vote. Either they had come to regard all politicians as self-serving, or they thought that, if the Labour party won, it would be removed in another coup. ${ }^{1}$

Both sides of the political divide had splintered, with different factions alternately coalescing and fighting with each other. The Labour Party, which ruled Fiji for a year before being ousted, was divided, with former University of the South Pacific academic and Deputy Prime Minister Tupeni Baba leading a breakaway New Labour Party that attracted many Labour party members disenchanted by former Prime Minister Mahendra Chaudry's behaviour. ${ }^{2}$ The Fijian parties were in equal disarray, with none of the factions appearing to have a clear chance of winning in its own right.

Even before the elections there were already clear losers, however. Sitiveni Rabuka, former Prime Minister and leader of the 1987 coup, decided not to contest the election after being unable to secure pre-selection. Rabuka had angered many influential Fijians, who felt he had insulted former Prime Minister and President Ratu Sir Kamesese Mara. Rabuka had also been the subject of rumours that he had appeared at the gate of Queen Victoria barracks in civilian clothes, but with his uniform on the back seat of the car, as if ready to offer his services or take command.

The other loser was George Speight, who remained locked up on Nukulau Island off Suva with 12 alleged accomplices. Attempts to secure his release so that he could contest the election came to nothing and he remained incarcerated. Despite this, he managed to win a seat in parliament. Speight's career as a politician was short lived, however. He was thrown out of parliament after he failed to attend the requisite number of sittings, something he found difficult to do while in prison.

But the real losers were the people of Fiji. Prince Gopal Lakshman, who was elected as a Labour Party member for the Indian communal constituency of Viti Levu South in the last parliament and was imprisoned by Speight, said F\$200 million in investment had flowed into the country during the Labour government's one year of rule. The economy boomed and people were able to eat a little better when Value Added Tax was removed from basic food items. ${ }^{3}$ All that ended on 19 May 2000. The economy was effectively crippled and grand projects like the new real estate developments at Pacific Harbour became uncertain. 'If they'd let us run the country for five years, Fiji would have been 20 years ahead', Prince Lakshman said. 'Instead, this coup has set us back 20 years.'

The most visible signs of the economic crisis could be seen on the streets. There have always been beggars on the streets of Suva, mostly widowed and abandoned Indian women who sit quietly outside the market with their hand out for a few coins. Now Fijians had joined them, striking up a conversation, politely asking for a cigarette and then gently turning the conversation to the matter of perhaps a few dollars for their children. Many children had stopped going to school because they did not have enough money for fees, or books or lunch and so their parents let them roam the streets to beg.

Fiji's Indians, as always, were hit hardest by the coup. With no traditional land to fall back on, those Indo-Fijians at the bottom of the economic pile had always struggled the hardest to make ends meet. Now their small, hungry, shamed children sat on blankets, heads bowed, hands out for tourist coins. 


\section{BAPTISM OF FIRE}

The Fijians fared no better. Young Fijians, the urban, displaced, unemployed Fijians, had nowhere to go. They could go back to their villages and grow dalo or cut coconuts or catch fish, or they could stay in town and steal. Fijian landowners were becoming more disillusioned with their traditional leaders. The army was guarding the Monasavu hydroelectric dam from threats by landowners and the army had to be called in to ensure that western landowners did not carry out their threat to blockade Nadi international airport in another compensation dispute. 'They have woken up to the fact that Fijians are stealing from Fijians', one young Fijian said. ${ }^{5}$

Meanwhile, at the University of the South Pacific journalism students who had returned for the second semester were preparing to go out on the road to cover the run-up to the August elections. They would travel around the two main islands, Viti Levu and Vanua Levu, and report back on what they found. The students were eager to get back on the job. For them this was a natural continuation of what they had started 10 months before when George Speight and his thugs stormed parliament and gave the students a baptism of fire they would never forget.

The journalism programme at USP is the latest of several that have been attempted and the most successful. Funded largely by the French government for the first four years of its existence, the current programme was begun by former BBC World Service journalist François Turmel in 1994. As a regional university, USP attracts students from all over the Pacific and the Speight coup, and its painful aftermath, were covered by students from all over the Pacific.

The journalism students had already experienced the problems caused by the tensions that lie just beneath the surface in Fiji. Indo-Fijian journalism students were abused for their coverage of financial irregularities in the Indian and Fijian student councils. Fijian student association president Veresi Bainivualiku, known for his links with the taukei (native Fijian Nationalist) movement, led protests on campus and successfully disrupted the election of a new vice chancellor just before the coup. ${ }^{6}$

The Fijian and Indo-Fijian students had all grown up with strong memories, reinforced by years of discussion and bitterness, of what was by then referred to politely as 'the events of 1987 '. Many had hoped that the return to democracy and the election of the Labour government of Mahendra Chaudry would return the sense of balance and order society needed. But it was not to be. Already there were demonstrations by Fijian nationalists in the streets of Suva and there is now evidence that a plot had been hatched many months before to overthrow the government.

\section{May 2000}

On the morning of 19 May 2000, George Speight, a bankrupt kai loma (part European) businessman who reputedly spoke not a single word of Fijian and who spent most of his time in Brisbane, Australia, led an armed revolt against the elected government of Fiji. ${ }^{7}$

Mahendra Chaudry's government had been elected in the first elections under the new constitution that had been hammered out by Prime Minister (and 1987 coup leader) Sitiveni Rabuka and President Ratu Sir Kamesese Mara and 


\section{BAPTISM OF FIRE}

pushed through the Bose Levu Vakaturaga, the Great Council of Chiefs. Rabuka had expected to win and had campaigned on a platform that would have put him back in power alongside Jai Ram Reddy, an Indo-Fijian politician who was prepared to serve as his deputy in parliament. Instead, he was defeated and Chaudry and the Labour Party took over. From the start, Chaudry angered many people with what was seen as arrogance. It was said that on election night, he announced that the Labour party's victory was 'revenge for 1987'. If true, it was hardly a politic thing to say and there were many who thought that he should instead have immediately gone to the Great Council and publicly reassured the Fijians by making traditional gifts to the chiefs and pledging to support Fijian rights. ${ }^{8}$

Chaudry also upset the local media, particularly the powerful Murdochowned Fiji Times, and soon seemed to believe that the media were plotting against him. (On the other hand, USP journalism programme coordinator David Robie and other commentators believe that the Times did 'wage a relentless campaign against the fledgling government'.) ${ }^{9}$

Presiding over all of this as guardian of the country's constitution and the closest thing to a tui viti (king), was Ratu Sir Kamesese Mara, Fiji's first and longest serving prime minister and, in the wake of the Rabuka coup, president of the new republic. When Speight and his gang, a motley collection of kai colo (mountain people), squatters and disaffected soldiers stormed parliament, they were not repeating the events of $1987 .{ }^{10}$ While his actions in 1987 were clearly treasonable, Rabuka acted out of a genuine, if misplaced, belief that he was saving the Fijian people and fulfilling his duty as a loyal bati (warrior) to his paramount chief, Ratu Mara. ${ }^{11}$

Speight used the rhetoric of race to give himself credibility with the Taukei, but he was really the front for a battle between old chiefs and young chiefs, involving a new urbanized Fijian middle class that had grown up under Rabuka, between, as Stewart Firth, head of politics and history at USP, put it, "the traditional and modernity'. ${ }^{12}$

Speight had little credibility himself. He was embroiled in a controversy over a timber deal involving Fijian mahogany and had appeared in court just before the coup to face charges of exchange rate charges and extortion in the High Court in Suva. The offices of the timber company with which he was involved mysteriously burned down during the putsch. ${ }^{13}$

As far as anything can be ascertained from the tangle of truths, lies and myths that still surrounds the event, the Speight putsch was organized and promoted by a shadowy group of Fijian chiefs, politicians and businessmen who were interested in achieving their own ends regardless of the effect on their fellow Fijians. Speight was, to use Lenin's words, a useful idiot, a bald-headed thug who would oust a legitimately elected government, cause the resignation of Ratu Mara, destroy the Fijian economy and once more destroy the country's fragile racial harmony. ${ }^{14}$

USP's journalism students were involved with the coup right from the start. Many of the students were working for the local media and doing their degrees part time. Matelita Ragogo, a part-time journalism student was reporting for The Fiji Times in parliament when the putsch began. She was taken prisoner but later released. 


\section{BAPTISM OF FIRE}

The news of the insurrection was broken at 10am by Tamani Nair, a USP journalism student on attachment to Radio Fiji. He was listening to a live broadcast of parliament when he heard shots and shouting. He and another more senior journalist, Samisoni Pareti, rushed to parliament, only to find the gates locked and guarded by masked men.

We were told, 'Get the hell out of here!' So we hid in nearby cassava bushes and watched what was going on. ${ }^{15}$

As soon as he heard the news of the coup, journalism programme coordinator David Robie gathered the students.

After quick phone calls to confirm the facts, sketchy as they were at that stage, I met our senior student editors to decide what we would do. At that stage, it was felt that the crisis would be over in a few days and we decided to go all out to cover the events. Three months later the USP students were still covering the crisis. Wansolwara already had a team of reporters down at the protest march in downtown Suva that morning; the news editor set up radio and television monitors. The reporters were dispatched to Parliament; the television class was cancelled and a crew sent downtown to Suva where they filmed footage on the riots and arson in the capital. ${ }^{16}$

\section{May 2000}

About 20 students volunteered to cover the coup. Some went to parliament to keep an eye on the situation there, while others stayed in the newsroom to monitor the television and radio news. The students saw it as a 'great opportunity'. Solomon Islands student Alison Ofotolau said at the time: 'We are lucky to be reporting on a major world event.' ${ }^{17}$

For the next few days the students worked round the clock to cover the crisis. They put up digital photographs, audio clips and their own stories, as well as summaries drawn from monitoring the news on their own website, and also prepared to produce a special print edition of Wansolwara.

Speaking a year after the coup, Robie admitted that his students at one stage kept him in the dark about what they were doing. The university is close to the parliamentary complex and students found bush paths that led into the grounds. Speight manipulated the press masterfully and his thugs tried to terrorize any media outlet they did not like.

Violence flared across the whole country. A protest by Taukei (Fijian nationalists) on the morning of the putsch rapidly turned into rioting, with shop fronts smashed and buildings destroyed. In the rural areas, villagers terrorized Indian cane farmers and drove them off their land. The student journalists soon came under fire themselves.

The violence was also directed at the media. The worst incident came on 28 May when a group of Speight's supporters smashed their way into the studios of Fiji One in protest at a current affairs programme that had angered them. Fiji One was off air for 48 hours. Other journalists were threatened and others beaten. Despite the difficulties, the students carried on. It is not possible in an 


\section{BAPTISM OF FIRE}

article of this length to repeat everything the students saw or reported, but these extracts give an idea of what it was like in the first few days before martial law was declared.

Through their often very personal accounts of the coup we can catch a glimpse of the protracted negotiations with the Great Council of Chiefs, the slow erosion of Ratu Mara's power, the violence, the suspicious links between Speight and powerful political figures and the apparently complete unwillingness of anybody in Fiji to actually do anything to save Mahendra Chaudry's government.

\section{May 2000}

Swarms of people filled Suva's main streets today to take advantage of the political crisis and started looting large departmental stores.

Buses coming into the city were filled with people coming to witness the crisis as it unfolded before their eyes.

Tappoo Duty Free, Lala's store, and Jack's Handicraft were some of the stores that were targets for looters.

Crowds of people including teenagers moved together in groups awaiting people to make the first move to smash display windows before rushing in to loot the shops.

Police officers could not do much but arrest people as the looters ran amok through the streets with items they stole from shops.

The Central Police station in Suva was bustling with commotion as police officers drove in and out with van loads and truck loads of people they had arrested on the streets.

In the centre of the Suva's police premises was a mountain of stolen goods (which grew at an alarming rate) that the police had seized and the Suva police cell was filled with suspected looters.

However, looting and vandalism continued in most of the Suva business district. ${ }^{18}$

A curfew has now come into force after the declaration of a state of emergency in the Fiji Islands as police were clamping down on looters following this morning's take-over of government by armed masked men.

Assistant Police Commissioner Jahir Khan said anyone seeing walking the streets after $6 \mathrm{pm}$ would be arrested.

Nightclub owners have also been advised to stay closed tonight.

Director of the CID, Emosi Vunisa, said all the looters had been chased from the main streets in Suva by police holding iron rods and other weapons.

The looters had been moved to Suva Bus Station where police arranged for trucks to take them out of the city.

Stolen property was seized.

'Police have not requested for any military support yet', Mr Khan said. ${ }^{19}$

\section{May 2000}

The President of the Fiji Islands, Ratu Sir Kamisese Mara revealed today in a nationwide broadcast that the leader of the terrorist group holding the 


\section{BAPTISM OF FIRE}

government captive had warned that he would start executing hostages if the president did not step down.

Ratu Mara said in the Radio Fiji broadcast in English, Hindi and Fijian he refused to meet coup leader George Speight's demands.

Ratu Mara said he was legally empowered under the public emergency regulations to carry out the duties to promote law and order.

He said he was concerned that the arms used by the terrorist group were military issue and that Speight's armed men were members of a counterrevolutionary unit of the Royal Fiji Military Forces (RFMF).

Meanwhile, Fiji's military commander Frank Bainimarama has just arrived in Fiji from the Middle East and has been holding talks with the president.

In other developments of the day, the elected Prime Minister, Mahendra Chaudry, refused to comply with the kidnappers' pressure on him to resign. He has been held captive with his cabinet and at least 45 MPs within the Parliament complex since Friday morning. ${ }^{20}$

\section{May 2000}

We left the University of the South Pacific newsroom at $5.30 \mathrm{pm}$ last night on our newspaper Wansolwara's next round-the clock shift covering the attempted coup.

At the first checkpoint, we were told by the police that they had just received an order not to allow any more journalists within a 100 metre radius of the parliament complex.

We pleaded with the police officers at the first checkpoint to let us through because we wanted to be in time for the $6 \mathrm{pm}$ press conference. They refused and ordered the taxi driver to drive ahead to the second checkpoint, reverse the car and leave.

At the second checkpoint, we managed to convince police to let us through and we arrived at the back entrance of Parliament House at about $5.55 \mathrm{pm}$

At that very moment, the gates opened and a man walked out shouting: 'All media ... all media ... gather here please.'

[As we followed him to the gate] shots were fired from our right and we hit the ground for cover. A four-wheel drive vehicle sped from outside the gate and parked in front of it. By now, five men armed with M16 guns were in position from inside the gate defending it, while the rebel soldier who was escorting us took cover behind the vehicle parked in front of the gate.

About five minutes later, the rebel soldier behind the vehicle said: 'Move in one by one to the gate guard house.'

At the gate guardhouse, still in a crawling position, we had to show our ID cards to two men inside.

Five minutes later, the man escorting us said: 'OK everybody, up and walk in a single file.'

We got up and walked in a single file to a shelter inside the parliament complex.

[After the press conference] we met University of the South Pacific 
science lecturer Timoci Gaunavinaka who told us that he saw six soldiers in full military uniform at about $5.30 \mathrm{pm}$, carrying M16 guns at one of the checkpoints near parliament house. ${ }^{21}$

\section{May 2000}

The perpetrators of the civilian coup holding parliament under siege are claimed to be members of a Fijian elite who have lost out on government contracts following the defeat of the Rabuka government by Chaudry's Labour-led administration.

They have been described as 'members of a new Fijian middle class who had benefited from government contracts during the Rabuka regime, but lost out when the Labour-coalition government came to power a year ago' by a University of the South Pacific sociologist.

Dr Sitiveni Ratuva said the group was using 'indigenous rights' as an excuse to further their own personal self-interest, and that they supported privatisation of Fijian land for commercial development that will benefit them..$^{22}$

Rebel leader George Speight warned the Great Council of Chiefs would need to explain to the indigenous people of Fiji-not him-if its decision goes against his illegal take-over of Parliament.

'The council meeting is not a chance for me to succeed. I have to have you understand that this is not about me,' he said.

'I am just used as an instrument. If I have to die for these people, then I have to.'

If the Great Council of Chiefs did not back Speight's demands, it 'will have to explain to the people, not me'.

About 600 people were drinking grog $[k a v a]$ and singing inside the parliament complex this afternoon and Speight claimed that those were his 'soldiers'. ${ }^{23}$

\section{May 2000}

As much as I wanted to go to Fiji's Parliament, I was very aware that with my Indian looks crossing the line into the Parliament where all the indigenous Fijians were gathering, would be kind of scary. But journalism got the better of me and I took off to Parliament with two of my fellow student journalists, what awaited me there was a moment I would not forget for a long long time. I was not harassed, but eyes were certainly laid on me just curious and confused as to what an 'Indo-Fijian' was doing in an indigenous Fijian gathering.

Being kissed by the rebel leader was something-but being the only Indian-looking person in the middle of hundreds of indigenous Fijians made the day for me. ${ }^{24}$

[Noora Ali was actually an exchange student from the Maldive Islands]

25 May 2000

Fiji Hardwood Corporation (Fiji) Ltd was burnt to the ground early today.

Joe Rainima, head of the National Fire Authority, told Pacific Journalism Online the cause of the fire was suspected arson but he did not think anybody had been arrested in connection with it. 


\section{BAPTISM OF FIRE}

When the fire fighters got there, the building was already in flames and could not be saved. The Fiji Hardwood Corporation building is owned by Opposition MP Jim Ah Koy.

'Self-proclaimed' Prime Minister George Speight was a member of the board while Ah Koy was Finance Minister in the Rabuka government before he was sacked by the Chaudry government. ${ }^{25}$

\section{May 2000}

Staff members of the Fiji Broadcasting Corporation have been given 24hour police protection after reporters were threatened by a group claiming to represent coup leader George Speight, The Fiji Times reports.

Four policemen were posted outside the station this afternoon. ${ }^{26}$

\section{May 2000}

A group of unarmed soldiers marched into Fiji's Parliament today and pledged their support to rebel leader George Speight and his selfproclaimed government.

The 15 soldiers from the Engineer Infantry Unit of the Fiji Military Forces, reported to be led by the brother of Police Commissioner Isikia Savua, marched into the complex and pledged their support to Speight.

They were led by Major Jone Savua and Sergeant-Major Veisamasama.

A Pacific Journalism Online reporter at Parliament was told the men were 'deserters' supporting Speight. However, Fiji Television said: 'It is unclear what role the soldiers have.'

The men are believed to be from the Kubuna confederacy, which includes Speight's home province of Tailevu and the province of Naitasiri where the majority of supporters at Parliament come from.

During the day, more than 1000 supporters of Speight and the rebels moved freely around the Parliament complex where groups of women were entertaining the crowd with 'nationalist' songs exalting the Kubuna confederacy.

Military forces have stepped up security around the compound of Parliament.

Soldiers armed with M16 assault rifles barred the public from entering the parliamentary grounds.

Meanwhile, Speight and his advisers and a delegation from the Great Council of Chiefs continued negotiations.

A villager, Lepani Rogorogonivanua from Kaba in Tailevu, said: 'The villagers in Tailevu want George Speight to lead the country and not Ratu Mara.'

He said the chiefs should not act on the premise that they have the mandate of the grassroots people.

In a two-page letter to George Speight, the great council of chiefs proposed ten resolutions which were rejected outright. ${ }^{27}$

\section{May 2000}

A foreign cameraman, a Briton attached to Associated Press television news service, and two soldiers were taken to hospital today after being wounded in a shooting incident at a military checkpoint near the 


\section{BAPTISM OF FIRE}

Parliament complex.

A Pacific Journalism Online reporter on the scene-a checkpoint opposite the Suva Grammar School, near Parliament-named the APTN cameraman as Jerry Harmer.

Hamer and the soldiers were reported to be in stable condition.

One of the soldiers was reportedly shot in his upper arm while a second was shot in the leg.

[Another cameraman described what happened].

'Basically, there was a group of supporters who were brought by one of the gunmen. They marched outside the gates, breaking up the military checkpoints, stopping food supplies from coming in ' he said.

'Soldiers were firing in the air. I saw one soldier firing at the crowd and it just got crazy for a few minutes.' 28

\section{May 2000}

He asked me if he could meet me at the main gate and I said, yes, and followed him to the main gate. At the main gate another person which I knew by face, he is from Tailevu, said, 'None of you are allowed in here, get out or you will get shot.' ${ }^{29}$

\section{May 2000}

Fiji's new head of state, military commander Commodore Frank Bainimarama, who last night declared martial law, today issued three decrees, including revoking the 1997 multiracial constitution.

The three decrees were gazetted and five more are expected to follow.

According to national radio reports, the first decree revokes the 1997 constitution, the second enables the judiciary, public service and financial laws to continue, and the third provides the framework for the military government.

Decree One announced by the military is the Fiji Constitution Amendment Act 1997 Revocation Decree 2000. Other provisions may be restored in other decrees.

This means that the 1997 constitution which paved the way for Fiji's return to the Commonwealth and the first fully democratic elections since the 1987 military coups no longer exists, say political sources.

Decree Two is the Existing Laws Decree 2000. This means that all laws that existed before last night's military take-over-apart from the constitution itself-and any law that has no meaning without the constitution are retained. This means that the bulk of Fiji's legislation or laws remain in force.

Decree Three is the Interim Military Government and Finance Decree 2000 which sets out the basic structure for the new interim military government.

This contains vital provisions regarding governmental liability, contractual and otherwise.

Section 12 says that executive powers normally exercised by ministers on behalf of the President will now be vested in the head of the IMGCommodore Bainimarama. ${ }^{30}$ 


\section{BAPTISM OF FIRE}

By the time martial law was declared on 29 May, the students had posted 109 stories, dozens of audio reports and many digital photos on the Pacific Journalism online site. Most of the work was posted on the Pacific Journalism Online site and as the situation developed, the students found theirs was often the only perspective available to people outside Fiji. ${ }^{31}$

However, the most immediate threat to their work came from USP Vice Chancellor Esekia Solofa, who abruptly stopped Robie's students reporting on the coup by disconnecting the website. He also requested the print edition of Wansolwara be withheld pending scrutineering of the newspaper by university management staff and when he discovered that it had already gone to press he ordered that all copies be withheld for some weeks pending a further decision on a date when it could be released. However, Wansolwara was circulated as soon as it returned from the printers and Solofa subsequently gave permission for it to be distributed.

Solofa was concerned that the violence committed against journalists would spill onto campus and was doubtless mindful of the previous behaviour of Fijian nationalist students.

Robie and the other journalism staff requested a meeting with Solofa. Support from overseas organizations was organized and the Vice Chancellor received protests from Reporters sans Frontieres, CJA, NZJEA, Committee to Protect Journalists (New York).

In a letter to Robie, Solofa said the closure was based on considerations of safety of university property, staff and students.

'The decision I had taken to close down the Journalism Programme website was a straightforward decision based entirely on one consideration: the safety and security of the property of the University and of the lives of the people engaged in it. ${ }^{32}$ (Esekial Solofa, letter to David Robie, 22 June 2000)

The president of the USP staff association, Dr Briman Prasad, later told the annual conference of the New Zealand Association of University Staff that Solofa's actions amounted to a call for self-censorship. ${ }^{33}$

The School of Humanities Board of Studies condemned the shutdown on 25 July. Acting head of school Dr Desma Hughes said:

The coup gave our students an ideal opportunity to practise their journalism skills under the supervision of one of the school's professional staff members. We ... find it difficult to understand the rationale behind the decision to suspend the web site that deprived our students. ${ }^{34}$

The journalism students took pride in the risks they had taken and their success in overcoming them:

Student journalists chose to be on the job. But it hasn't been easy. They survived threats, bureaucratic attempts to gag their web site and newspaper and a shutdown of the university to deliver news. Grabbing the opportunity to hone their skills, the young journalists didn't waste any time rushing to be on the spot at Parliament on May 19 and the looting and arson sites around the capital, Suva. ${ }^{35}$ 


\section{BAPTISM OF FIRE}

The site was eventually allowed to reappear on 28 June, but with no news of the putsch. In the meantime, the students' reporting reappeared on mirror sites set up by the University of Technology in Sydney and by former USP Media Centre employee Mara Fulmar in the USA. ${ }^{36}$ At several points the students' website was the only source of information about the coup for people living outside Fiji as commercial websites went offline.

A New Zealand reader wrote to the students, saying: "Your coverage of the coup is simply phenomenal. Thanks for doing the international community this tremendous service. ${ }^{37}$ A reader from the UK said: 'It's good to see you online as the news of the coup reaching Europe is vague and one-sided.' ${ }^{38}$

Commonwealth Journalists Association President Murray Burt described the students' work as:

For the most part ... excellent-tempered, insightful, lawful and credible in its very closeness to the action. There has been a measure of bravery, too, which should not be forgotten when the dust settles. ${ }^{39}$

At the end of 2000, the Australian Journalism Education Association made Ossie awards for journalism students to Wansolwara and the journalism website for their coverage of the coup. ${ }^{40}$ The judges said the students rose to the challenge of providing high quality reports of a dramatic international news event on their doorstep. "They did so in challenging circumstances ... on the internet [and] were one of the few sources of information at critical times of the events taking place.' ${ }^{41}$

The USP students won the Dr Charles Stuart prize for best publication overall (Pacific Journalism Online), while the newspaper (Wansolwara) was highly commended for best newspaper and best publication overall. Students Christine Gounder (best TV news story), Losana McGowan (best print news story), and Tamani Nair (best radio) were also highly commended by the judges. ${ }^{42}$

\section{Aftermath}

Because of the disruption caused by the coup and its proximity to parliament, USP closed down early and sent home about 5000 students, among them some of the young journalists who had been covering the coup. Samoan journalism student Laufaleaina Eli recalled that she had been in and out of the journalism newsroom for as long as she could but, like most Samoan students, spent a great deal of time waiting for her government to decide what to do. In the end, the Samoan government evacuated its students on 26 May.

The USP journalism students' coverage continued, but with the work mainly being done by Fiji residents, some of whom were also working for the local media. The Pacific Journalism Online website did not come back until 27 June.

The crisis continued to stumble along in its own peculiarly Fijian way. As Chris Masters put it on Four Corners:

So the coup proceeded in slow motion-too slow for most of the accompanying media. The negotiators came and went. There was a lot of talking -in Fiji style and Fiji time. ${ }^{43}$

Paul Geraghty (Qarase) said on the same programme: 


\section{BAPTISM OF FIRE}

Fijians never stay enemies for very long ... Your drink with your enemy, you talk with the enemy ... and you try to get things sorted out in a civilised fashion. ${ }^{44}$

The Speight putsch brought to the surface long-standing tensions between the eastern and western confederacies of Fiji's main island, Viti Levu, and the northern confederacy of Vanua Levu. When Rabuka overthrew the Bavadra government in 1987, race was a genuine factor. This time, however, the tension between Fijians and Indo-Fijians had been exploited for purposes that went far beyond satisfying the expectations of die-hard Fijian nationalists. Writing at the time, Teresia Teaiwa, lecturer in Pacific Studies at Victoria University of Wellington in New Zealand, said the 'real struggle is amongst indigenous Fijians, and it is continually masked by the rhetoric of a racial conflict between indigenous Fijians and Indo-Fijians' ${ }^{45}$

Teaiwa saw a struggle for power between competing interests from the eastern and western confederacies of Viti Levu, between the supporters of the older leaders, especially the president, Ratu Sir Kamisese Ratu Mara, and the new generation of rich Fijians who gained power after the 1997 coup. $^{46}$ Many believed the putsch was carefully planned. According to Jone Dakuvula, former adviser to opposition leader Ratu Inoke Kubuabola, a group was formed in 2000 to run a destabilization campaign against the Chaudry government. $\mathrm{He}$ quoted Ratu Inoke as telling a meeting of the SVT party on 27 March 1999, that they 'must be prepared to fight and to shed blood if need be' to restore power to indigenous Fijians. Dakuvula said he did not know whether Ratu Inoke knew what Speight was up to. ${ }^{47}$

Fiji historian Brij Lal described Speight as:

the front man for a variety of interests, including the radical nationalist Fijians operating on the fringes of indigenous politics and opportunistic Fijian politicians defeated at the last elections keen to settle old scores. ${ }^{48}$

\section{July 2001}

Ten months after the coup, the people of Fiji prepared to go to the polls. Any certainties that might have existed among the plotters had vanished. For everybody else, bitterness was all that remained. The racial rivalry that many outsiders had mistakenly said was the sole reason for the coup was still there, but many Fijians appeared to think they had been betrayed by their own people. 'We all bleed. We're all the same', said Tui, an angry young indigenous Fijian. 'Without the Indians, Fiji will never go anywhere in its life.' ${ }^{49}$

Robie said the students were keen to provide independent and different coverage of the election from that provided by the mainstream media.

The mainstream media is focussing on slanging matches between the different parties. Our focus will be the issues and whether the different parties take notice of the needs of the grass roots. This experience will give students a tremendous sense of purpose which will serve them well in the future. ${ }^{50}$

At USP, Peter Emberson had been elected as editor for the election coverage. 


\section{BAPTISM OF FIRE}

He had been one of the students involved in the coup coverage and now he organized a volunteer team that included students with experience of the coup as well as a number of working journalists. ${ }^{51}$ USP journalism student Reggie Dutt visited Fiji's second largest island, Vanua Levu, and found campaigning almost at a standstill. He said voters were confused about who to vote for and there was an air of uncertainty, with people showing little open interest in this election, in contrast to urban and rural areas on the main island of Viti Levu. ${ }^{2}$ 'For me, this election has no meaning', one resident said. 'I have voted in two governments, one in 1987 and one in 1999-and look what happened to them.' ${ }_{53}$

But people did vote, with a surprisingly high turnout. The result was one that solved nothing immediately. Interim Prime Minister Laisenia Qarase, who had never previously been elected to public office, won and promptly refused to abide by the constitutional requirement that he offer seats in his cabinet to Labour members. ${ }^{54}$

The judiciary worked overtime with constitutional arguments, the prosecution of the rebels and with trying to find some compromise that would satisfy enough people of all races. Prime Minister Qarase declared at one stage that Western democracy simply had no place in Fiji and has established a relationship with the media that sometimes seems to be every bit as bad as Chaudry's. But since he has recently declared that the putsch and his election victory were God's will, perhaps he simply doesn't have to care what the newspapers think. ${ }^{55}$

Through it all, USP's journalism students have kept reporting. The archives of stories are still there on the Pacific Journalism Online site and in the UTS archives. More importantly, the spirit of the coup is still there in the journalism course and in the attitudes and experiences the students will take with them into the workplace when they graduate and return to their home islands.

\section{Useful websites}

USP Pacific Journalism Online: http://www.usp.ac.fj/journ/

Wansolwara Online (USP): http://www.usp.ac.fj/journ/docs/news/index.html Archive of USP coverage http://www.usp.ac.fj/journ/docs/news/cpunews.html

\section{Mirror sites}

Lookinglass Design http://www.lookinglassdesign.com/wansolwara/wansol. html

University of Technology Sydney archive of USP journalism stories http:// www.journalism.uts.edu.au/archive/fiji_coup/index.html

\section{Notes}

1 Radio New Zealand International, 9 July 2001.

2 Wansolwara Online, 22 August 2001.

3 Author's interview with Prince Gopal Lakshman, Suva, 20 July 2001.

4 Ibid.

5 Author's interview with Prince Lakshman, Suva, 19 July 2001.

6 On the eve of the Speight putsch, Bainivualiki and other ultra-nationalist students led protests which cowed the USP council into changing its mind about appointing 


\section{BAPTISM OF FIRE}

Dr Rajesh Chandra as Vice Chancellor. 'USP trouble with student leader', Pacnews, 21 August 2000.

$7 \quad$ Kai loma means literally 'person of mixed race'.

8 In an interview with Fiji One, Ratu Mara suggested that Chaudhry might have stayed in power if senior members of his party had been able to persuade him to modify his behaviour. Interview with Ratu Mara on Close-up, Fiji One, 1 May 2001.

9 According to AFP journalist Michael Field, Chaudhry asked in October 1999 whether The Fiji Times was supporting people engaged in sedition. 'Furious row as academic suggests Fiji's media helped cause a coup', Agence France Press, 17 December 2000.

10 Tui viti means lierally 'chief of Fiji.' There has never been such an office, despite Cakobau's pretensions to the contrary when he handed over Fiji to Britain. Kai colo means 'village born.'

11 Mara has always denied that he authorized the 1987 coup and tried to suppress a 1997 biography of Rabuka in which he explicitly claimed to have acted with Ratu Mara's blessing. See John Sharpham, Rabuka of Fiji, Rockhampton: Central Queensland University Press, 2000. In a television interview in 2001 Mara said Rabuka may have 'misinterpreted' some of his remarks. Interview with Ratu Mara on Close-up, broadcast on Fiji One, 1 May 2001. Bati means 'warrior'.

12 'Race at heart of Fiji ruling', at http://onenews.nzoom.com/news_detail/0,1227, 31312-1-9 00.htm.

13 David Robie, 'Gunmen seize control', Pacific Journalism Online, 20 May 2000.

14 Speight's partner, Torika Rawlinson, claimed later that Speight actually saved the Chaudhry government by kidnapping it, alleging that the original plan had been to assassinate cabinet members at home on the night of 18/19 May. Kelera Muasevi, 'It could have been worse-Speight's Torika', Wansolwara Online, 25 May 2002. Her claims about Speight's kindness seem somewhat disingenuous in the light of Prince Lakshman's report that, on a number of occasions while he was held prisoner, the parliamentarians were gathered together and made to lie on the floor as if they were about to be shot. Author's interview with Prince Lakshman, Suva, 20 July 2001.

15 David Robie, 'Ethics amid brinkmanship', Commonwealth Press Union News, August 2000.

16 David Robie, 'Journalism education in the South Pacific', Phd thesis, 2002. Student Reama Naco recalls Robie bursting into her television class with Samantha Magick and exclaiming: 'Excuse me, do you know there's been a coup?'

17 Christine Gounder, 'Taking a coup in your stride', Commonwealth Press Union News, August 2000.

18 Peter Emberson, 'Looters plunder Suva stores', Pacific Journalism Online, 19 May 2000.

19 Losana McGowan, 'State of emergency declared', Pacific Journalism Online, 19 May 2000.

20 Peter Emberson, 'Ratu Mara tells of rebel execution warning', Pacific Journalism Online, 21 May 2000.

21 Joe Yaya and Harry Aurere, 'USP Journalism students caught in the crossfire', Pacific Journalism Online, 22 May 2000.

22 Joe Yaya, 'Dissident group after own personal gain: lecturer', Pacific Journalism Online, 23 May 2000.

23 Johnety Jerette, 'Speight warns council may need to explain', Pacific Journalism Online, 23 May 2000. 


\section{BAPTISM OF FIRE}

24 Noora Ali, 'The day I was kissed by a coup leader', Pacific Journalism Online, 24 May 2000.

25 Sheryl Ho, 'Fiji Hardwood building burned down', Pacific Journalism Online, 25 May 2000.

26 'Journalists threatened in hostage crisis', Pacific Journalism Online, 25 May 2000.

27 Joe Yaya, Alison Ofotalau and Isikeli Sauliga, 'Unarmed soldiers join Speight's rebels', Pacific Journalism Online, 26 May 2000.

28 Alison Ofotalau, Salesh Kumar and Isikeli Sauliga, 'Cameraman, two soldiers injured in gunfire', Pacific Journalism Online, 27 May 2000.

29 Amanda Smith, 'Wansolwara reporter threatened at Parliament', Pacific Journalism Online, 29 May 2000.

30 Alison Ofotalau and Amanda Smith, 'Three new decrees revoke Fiji's constitution', Pacific Journalism Online, 30 May 2000.

31 Robie, 'Journalism education in the South Pacific', op cit, Ref 16.

32 Esekia Solofa, letter to David Robie, 22 June 2000.

33 Ibid.

34 Dr Desma Hughes, letter to USP academic committee, 11 September 2001.

35 Christine Gounder 'Taking a coup in your stride', op cit, Ref 17.

36 'The students ... have truly earned their journo stripes', Mara said. http://www. lookinglassdesign.com/wansolwara/wansol.html.

37 Christine Gounder 'Taking a coup in your stride', op cit, Ref 17.

38 Ibid.

39 Ibid.

40 'USP student journalists win Ossies for Fiji coup coverage', Pacific Media Watch PMW3142, 11 December 2000.

41 Mark Pearson, 'Ossies recognise promising talent of future', PANPA Bulletin, February 2001.

42 Ibid.

43 Chris Masters, 'Cyclone George', Four Corners, 10 July 2000.

44 Ibid.

45 Teresia Taiwa, 'An analysis of the current political crisis in Fiji', Te Karere Ipurangi.

46 Ibid.

47 Jone Dakuvula, 'What should happen if Speight gives up?', Pacific Islands Report, 24 May 2000.

48 Brij Lal, 'Fiji: damaged democracy', Pacific Islands Report, 24 May 2000.

49 'Race at heart of Fiji ruling', at http://onenews.nzoom.com/news_detail/0,1227, 31312-1-9 00.htm.

50 Author's interview with David Robie, Suva, 18 July 2001.

51 Author's interview with Peter Emberson, Suva, 20 July 2001.

52 Reggie Dutt, 'Ghost town politics hits cane belt north', Wansolwara Online, 12 August 2001.

53 Ibid.

54 Andrea Waqa and Aterina Samisoni, 'Record turnout tipped in poll day 3 success', Wansolwara Online, 29 August 2001; and Joe Yaya and Latu Matoto, 'Qarase's cabinet excludes Indo-Fijians', Wansolwara Online, 12 September 2001.

55 'No place for western democracy in Fiji says Qarase,' Daily Post, 11 February 2000; 'Regime PM criticises Fiji media at magazine launch', Pacific Media Watch 3163 Media, 24 January 2001; and 'God chose me, says Fiji PM', Fiji Sun, 21 May 2000. 
Copyright of Round Table is the property of Carfax Publishing Company and its content may not be copied or emailed to multiple sites or posted to a listserv without the copyright holder's express written permission. However, users may print, download, or email articles for individual use. 